\title{
Seasonal pattern of Chrysomelidae (Coleoptera) in the state of Paraná, southern Brazil
}

\author{
Adelita Maria Linzmeier ${ }^{1,3}$ \& Cibele Stramare Ribeiro-Costa ${ }^{2}$ \\ ${ }^{1}$ Programa de Pós-graduação em Entomologia e Conservação da Biodiversidade, \\ Faculdade de Ciências Biológicas e Ambientais, Universidade Federal da Grande Dourados - UFGD, \\ CEP 79804-970, Dourados, MS, Brazil \\ ${ }^{2}$ Laboratório de Sistemática e Bioecologia de Coleoptera, Departamento de Zoologia, \\ Universidade Federal do Paraná - UFPR, CEP 81531-980, Curitiba, PR, Brazil \\ ${ }^{3}$ Corresponding author: Adelita Maria Linzmeier, e-mail: alinzmeier@yahoo.com.br
}

LINZMEIER, A.M. \& RIBEIRO-COSTA, C.S. Seasonal pattern of Chrysomelidae (Coleoptera) in the state of Paraná, southern Brazil. Biota Neotrop. 13(1): http://www.biotaneotropica.org.br/v13n1/en/ abstract?article+bn04013012013

\begin{abstract}
The aim of this paper was to describe the seasonal patterns of Chrysomelidae and of its most abundant species at eight sites in different geomorphological and floristic regions in the state of Paraná, southern Brazil. Samples with Malaise traps, from August 1986 to July 1988 were performed. The Chrysomelidae showed seasonal patterns with the highest abundance in the spring and/or summer at all sites, but with variations in the months of highest captures. Photoperiod was the variable that most influenced the seasonality of Chrysomelidae, and along with temperature and relative humidity, determined most of the seasonal patterns of the family at the different sites. Some dominant species of Chrysomelidae showed different seasonal pattern compared to the family level. A better knowledge of the seasonal distribution patterns of these species will only be possible when their life history, such as host plants and behavior, was better understood.
\end{abstract}

Keywords: abundance, Alticini, herbivorous insects, distribution pattern, seasonality.

LINZMEIER, A.M. \& RIBEIRO-COSTA, C.S. Padrão sazonal de Chrysomelidae (Coleoptera) no estado do Paraná, sul do Brasil. Biota Neotrop. 13(1): http://www.biotaneotropica.org.br/v13n1/pt/ abstract?article+bn04013012013

Resumo: O objetivo deste estudo foi descrever os padrões de sazonalidade de Chrysomelidae e de suas espécies dominantes, capturadas em oito locais de diferentes regiões geomorfológicas e florísticas do estado do Paraná, sul do Brasil. As coletas foram realizadas com armadilha Malaise de agosto/1986 a julho/1988. Chrysomelidae apresentou padrão sazonal com picos de abundância na primavera e/ou verão em todos os locais, mas com variações quanto aos meses de maior captura. O fotoperíodo foi a variável com maior influência na sazonalidade de Chrysomelidae e juntamente com a temperatura e umidade relativa, determinaram a maioria dos padrões sazonais da família nos diferentes locais. Algumas das espécies dominantes de Chrysomelidae apresentaram padrão sazonal distinto do observado para a família. O entendimento dos padrões de distribuição das espécies de Chrysomelidae somente será possível quando informações sobre a história de vida, como plantas hospedeiras e comportamento, forem melhor esclarecidas.

Palavras-chave: abundância, Alticini, insetos herbívoros, padrão de distribuição, sazonalidade. 


\section{Introduction}

The complexity of the habitat is a determinant for the evolution of seasonal adaptations of species (Danks 2007). As habitats also vary in space and time, to know how organisms behave in different environments and the extent of this variation is essential to a complete understanding of seasonal patterns, since these patterns are not always established as imagined (Wolda 1979).

Among the abiotic variables, photoperiod, temperature and rainfall are the main factors that act directly on species seasonal activity, besides determining other characteristics that affect the survival of insects, such as food availability (Wolda 1978a, 1988, Marinoni \& Ganho 2003, Linzmeier \& Ribeiro-Costa 2008). The biotic variables are more complex and difficult to determine because the organisms interact (e.g., parasitism, predation and competition) and the effects of these interactions are dynamic (Danks 2007). These variables are not always adequately described, but when examined they help clarify the phenological patterns and life strategies of populations.

Coleoptera is the most diverse order of insects, with about 360,000 described species (Bouchard et al. 2009). Beetles occupy a wide range of habitats, where they can be predators, herbivores or saprophages. Among these, the Chrysomelidae stand out as one of the most diverse families, with over 36,000 species, most of them occurring in the Neotropics (Costa 2000, Bouchard et al. 2009). They are essentially herbivorous, feeding preferably on Solanaceae, Cucurbitaceae, Convolvulaceae, Asteraceae and Poaceae (Jolivet 1988, 1992, Jolivet \& Hawkeswood 1995). Mainly for herbivores, climate changes impact both the spatial and temporal dynamics (Netherer \& Schopf 2010), and in this group, one of the most important factors is the interaction with the host plants, which are also influenced by abiotic factors. However, the same factors, climate and host plants, can affect their populations in different ways in different places.

Although the Chrysomelidae are a very abundant group in different surveys (Basset \& Samuelson 1996, Marinoni \& Dutra 1997, Ganho \& Marinoni 2003, Linzmeier et al. 2006, Riedel et al. 2007, Linzmeier \& Ribeiro-Costa 2012), their seasonality has not been addressed. The only study was conducted by Linzmeier \& Ribeiro-Costa (2008), who reported at one site, Ponta Grossa, Paraná, the highest abundances of Chrysomelidae in the spring and summer, probably because of greater food availability and quality. Moreover the authors indicated photoperiod and temperature as the abiotic factors that most influenced the Chrysomelidae seasonal pattern.

Therefore, we aimed to test the hypothesis that even at different sites, the peak abundances of Chrysomelidae occur in the same seasons recorded by Linzmeier \& Ribeiro-Costa (2008). It was also our aim to test whether photoperiod and temperature are the abiotic factors that most strongly influence the seasonality of Chrysomelidae at different sites. As this is one of the most species rich family within Coleoptera (Bouchard et al. 2009), and one of the most frequently sampled in terms of individuals in many surveys, mainly with malaise traps (Marinoni \& Dutra 1993, Ganho \& Marinoni 2003, Furth et al. 2003, Linzmeier et al. 2006, Linzmeier \& Ribeiro-Costa 2012) it is expected that its seasonality should represent the seasonal activity pattern of Coleoptera, and similarly, the dominant species would represent the distribution pattern of the family at each site where they were sampled. Furthermore, we intended to evaluate whether there are differences in seasonal patterns between sampling years and to determine the seasonal pattern of the ten most abundant species sampled, seeking to identify which abiotic factors analyzed have a greater influence on their seasonal distributions.

\section{Materials and Methods}

\section{Sampling sites}

Beetles were collected at eight sites located in different geomorphologic and floristic regions in the state of Paraná (Figure 1). They are as follows:

Antonina (25 $28^{\prime} \mathrm{S}$ and $\left.48^{\circ} 50^{\prime} \mathrm{W}\right)$ : coastal area, at Reserva Biológica Sapitanduva, old road from Morretes to Antonina, about $60 \mathrm{~m}$ a.s.l. Site well preserved and fairly representative of the region, dominated by submontane atlantic rainforest (Veloso \& Góes-Filho 1982).

São José dos Pinhais (25 $34^{\prime} \mathrm{S}$ and $\left.49^{\circ} 01^{\prime} \mathrm{W}\right)$ ): coastal mountain, $4 \mathrm{~km}$ from $\mathrm{km} 54$ of BR-277, approximately 1,050 m a.s.l. Transitional area between montane atlantic rainforest and montane Araucaria mixed forest (Veloso \& Góes-Filho 1982).

Colombo (25 $20^{\prime} \mathrm{S}$ and $\left.49^{\circ} 14^{\prime} \mathrm{W}\right)$ : first plateau, at the property of the Empresa Brasileira de Pesquisa Agropecuária (EMBRAPA), Highway Curitiba - Adrianópolis, old Road of Ribeira, km 19 (BR476), approximately $915 \mathrm{~m}$ a.s.l. The region is characterized as montane Araucaria mixed forest (Veloso \& Góes-Filho 1982).

Ponta Grossa (25 $14^{\prime} \mathrm{S}$ and $\left.50^{\circ} 03^{\prime} \mathrm{W}\right)$ : second plateau, in the Parque Estadual de Vila Velha, Café road, BR-376, km 83, about 880 m a.s.l., where montane Araucaria mixed forest dominates (Veloso \& Góes-Filho 1982).

Telêmaco Borba $\left(24^{\circ} 17^{\prime} \mathrm{S}\right.$ and $\left.50^{\circ} 37^{\prime} \mathrm{W}\right)$ : second plateau, at Reserva Biológica Samuel Klabin, about $4 \mathrm{~km}$ from Harmonia, highway Telêmaco Borba - Curiúva, approximately $750 \mathrm{~m}$ a.s.1. Also characterized as montane Araucaria mixed forest (Veloso \& Góes-Filho 1982).

Guarapuava $\left(25^{\circ} 40^{\prime} \mathrm{S}\right.$ and $\left.52^{\circ} 01^{\prime} \mathrm{W}\right)$ : third plateau, at Estância Santa Clara, in the valley of Jordão River, about 740 m a.s.l., wedged in a grassland region (Guarapuava fields). Transitional locality between Araucaria mixed forest and semi-deciduous forest (Veloso \& Góes-Filho 1982).

Jundiaí do Sul $\left(23^{\circ} 26^{\prime} \mathrm{S}\right.$ and $\left.50^{\circ} 16^{\prime} \mathrm{W}\right)$ : second plateau, at Monte Verde farm, about $500 \mathrm{~m}$ a.s.l. The site is approximately 400 ha of mostly primary forest with remaining portions consisting of secondary forest with more than 45 years of preservation. It is dominated by semi-deciduous forest (Veloso \& Góes-Filho 1982).

Fênix ( $23^{\circ} 54^{\prime} \mathrm{S}$ and $51^{\circ} 58^{\prime} \mathrm{W}$ ): third plateau, at Reserva Estadual de Vila Rica, $2 \mathrm{~km}$ from Fênix city, approximately $350 \mathrm{~m}$ a.s.l. The reserve, which is on the banks of the Ivaí and Corumbataí rivers, is characterized as semi-deciduous forest (Veloso \& Góes-Filho 1982).

\section{Beetle collection}

A Malaise trap was placed at each sampling site with its intercepting axis positioned north-south with the pot collector north positioned and, perpendicular to a track at the forest. The local chosen were little disturbed or best preserved possible. The samplings were uninterrupted over two years, from August 1986 to July 1988, with material removed weekly. All beetles were sorted from other Orders, mounted and labeled, and the chrysomelids were identified to the lowest taxonomic level possible following the classification of Reid (1995). The material is deposited in the Coleção de Entomologia Pe. Jesus Santiago Moure, Department of Zoology, Universidade Federal do Paraná (DZUP).

\section{Data analysis}

The seasonality of Chrysomelidae and the ten dominant species was based on mean capture numbers (abundance per month/number of samples in the month) because some months have five weeks, other four, and in some sites samples were lost. To adjust the sample period 


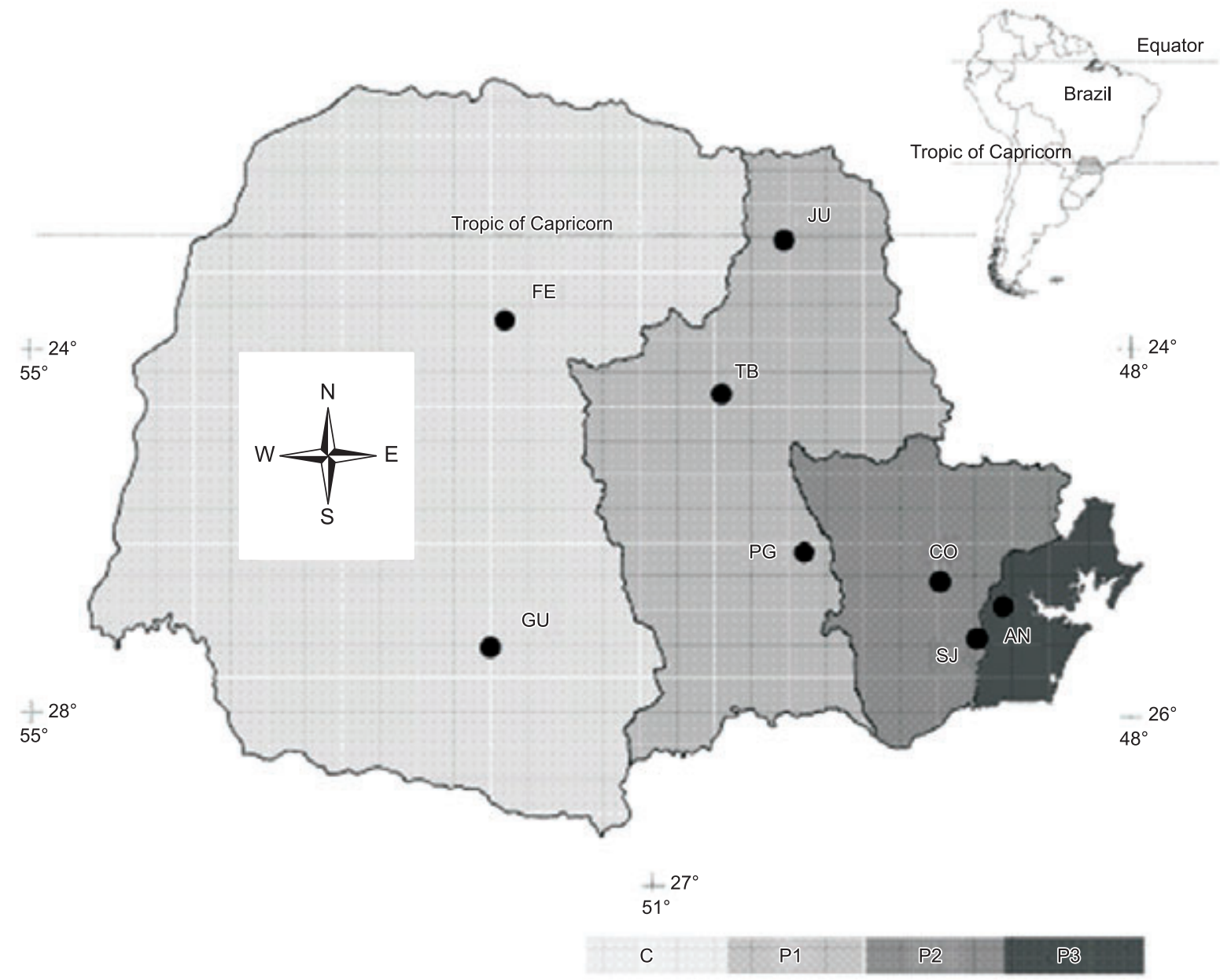

Figure 1. Paraná State, Brazil (modified from Riedel et al. 2007) showing the sampling sites in different geomorphological regions. ANT: Antonina, SJ: São José dos Pinhais, CO: Colombo, PG: Ponta Grossa, TB: Telêmaco Borba, GUA: Guarapuava, JU: Jundiaí do Sul, FE: Fênix; C: Costal region; P1, P2 and P3 show the First, Second and Third Plateaus respectively.

to the seasons, spring was considered from September to November, summer from December to February, autumn from March to May, and winter from June to August. Therefore, the first and the last two months were not considered. The seasons abundance was the sum of the mean abundance of their respectively months, and the seasons richness was the total number of species sampled in each season.

The meteorological variables analyzed were: maximum and minimum temperatures, rainfall and relative humidity, based on monthly means. Another variable analyzed was the photoperiod, obtained from the Anuário Interativo do Observatório Nacional (Moreira 2009). Since the sampling sites show no significant latitudinal variation, only photoperiod data from Ponta Grossa were used. More information about the weather stations can be found in Marinoni \& Dutra (1993). Spearman correlation analyses (Lehmann \& D'Abrera 1998) were performed between the monthly mean of Chrysomelidae, as well as each one of the ten dominant species, and the abiotic variables. To verify if the seasonal patterns of Chrysomelidae and Coleoptera, and of Chrysomelidae and the two most abundant species of each site are correlated, this same analysis was also performed.

Analysis of variance (5\% level of significance) was performed in order to determine if there was a significant difference in the abundance of Chrysomelidae collected between years and among sites. Normality of data was assessed by the Kolmogorov-Smirnov (KS) test, and when necessary, the data were log transformed.
Analyses were performed using the software STATISTICA 8.0 (StatSoft 2007).

\section{Results}

\section{Seasonal pattern of Chrysomelidae}

Of the 7,611 chrysomelids collected, the highest number was reached in the second year (Table 1). Only Jundiaí do Sul showed a significant difference $\left(\mathrm{F}_{1,22}=9.57 ; \mathrm{p}=0.005\right)$ in abundance between years, with $69.8 \%$ collected in the first year. However, there was a great but not significant increase in abundance in the second year in São José dos Pinhais (Table 1).

In general, there was one clear peak of abundance per year (Figure 2). In Antonina the peaks occurred in November in the first year and in January in the second, with the largest catch in the second year. In São José dos Pinhais, the peaks were in December in both years. In Colombo, the peaks were in January, and there was a larger catch in the second year. In Ponta Grossa, there were two similar peaks in the first year, in October and January; in the second year, the peak occurred in September. In Telêmaco Borba the peaks were in November, and the higher value was in the first year. For Guarapuava and Jundiaí do Sul, the peaks were in November in the first year and in October in the second. Finally, in Fênix, the peaks were in October in the first year and in September in the second. In 

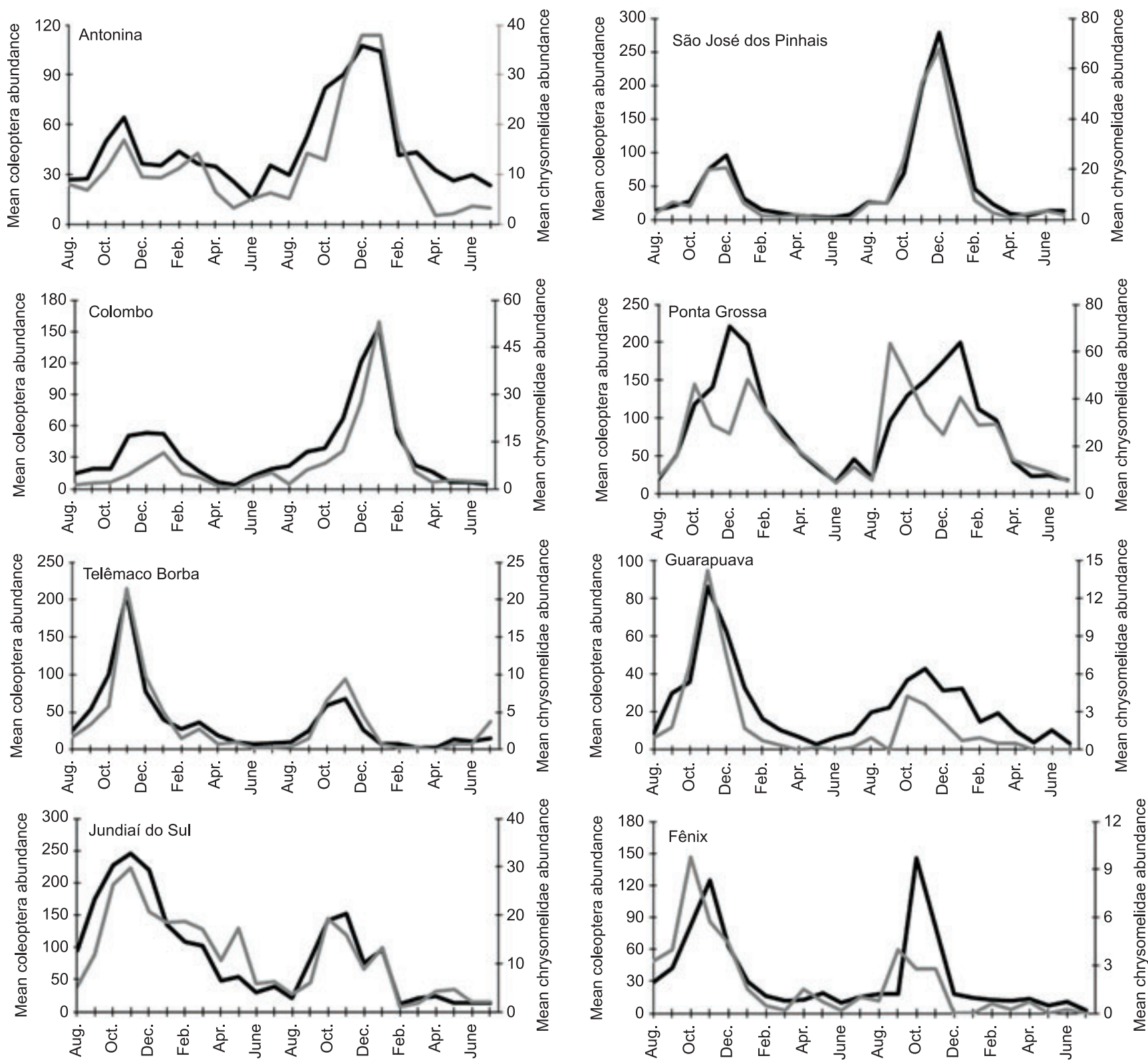

Figure 2. Seasonal distribution pattern of Coleoptera and Chrysomelidae sampled with Malaise trap in eight sites of the state of Paraná, Brazil, from August 1986 to July 1988. * Dark line: Coleoptera; gray line: Chrysomelidae.

Table 1. Abundance of Chrysomelidae (N) sampled with Malaise traps in eight sites of the state of Paraná, Brazil, from August 1986 to July 1988, and its correlation values with the meteorological variables. Values followed by * have significant correlation $(\mathrm{p}<0.05)$.

\begin{tabular}{|c|c|c|c|c|c|c|c|}
\hline \multirow{2}{*}{ Site } & \multicolumn{2}{|c|}{ Total abundance } & \multicolumn{5}{|c|}{ Correlation values } \\
\hline & $1^{\text {st }}$ year & $2^{\text {nd }}$ year & $\mathbf{T}_{\max }$ & $\mathbf{T}_{\min }$ & RH & Rain & $\mathbf{P P}$ \\
\hline Antonina & 455 & 752 & $0.58 *$ & $0.49 *$ & $-0.63 *$ & 0.09 & $0.73 *$ \\
\hline São José dos Pinhais & 299 & 906 & 0.36 & 0.36 & 0.04 & 0.17 & $0.65 *$ \\
\hline Colombo & 207 & 580 & $0.58 *$ & $0.50 *$ & -0.34 & 0.05 & $0.58 *$ \\
\hline Ponta Grossa & 1,160 & 1,342 & $0.49 *$ & $0.50 *$ & -0.15 & -0.11 & $0.69 *$ \\
\hline Telêmaco Borba & 231 & 126 & 0.38 & 0.15 & $-0.41 *$ & 0.23 & $0.54 *$ \\
\hline Guarapuava & 148 & 59 & 0.40 & 0.17 & $-0.46 *$ & -0.02 & $0.55 *$ \\
\hline Jundiaí do Sul & 808 & 349 & $0.50 *$ & $0.45^{*}$ & -0.30 & 0.27 & $0.59 *$ \\
\hline Fênix & 140 & 49 & 0.09 & 0.17 & $-0.73 *$ & -0.15 & 0.30 \\
\hline Total & 3,448 & 4,163 & & & & & \\
\hline
\end{tabular}

$\mathrm{T}_{\max }:$ maximum temperature; $\mathrm{T}_{\min }$ : minimum temperature; $\mathrm{RH}$ : relative humidity; Rain: rainfall; PP: photoperiod. 
São José dos Pinhais, Colombo, Telêmaco Borba, Guarapuava and Fênix, the peaks were very evident. However, at the other sites, there were several smaller peaks throughout the period.

Photoperiod was the abiotic factor most influenced positively the Chrysomelidae seasonality at the sites, excepting Fenix. In this site only relative humidity had significant and negative correlation value (Table 1). Besides, in Antonina significant correlations were also obtained with temperature and relative humidity; in Colombo, Ponta Grossa and Jundiaí do Sul with temperature; in Telêmaco Borba and Guarapuava with relative humidity (Table 1).

The seasonal distribution pattern of Chrysomelidae and total Coleoptera were very similar, with high and significant correlation values, even when data of Chrysomelidae was removed of the total Coleoptera, with exception of Ponta Grossa and Fênix (Figure 2; Table 2). Only in Ponta Grossa the correlation value decreased considerably (to 0.54) when data of Chrysomelidae was removed from Coleoptera.

The seasonal pattern of Chrysomelidae and the most abundant species of each site had significant positive correlation values in Antonina, São José dos Pinhais, Colombo, Ponta Grossa and Fênix, and in Colombo and Fênix the second most abundant species also had significant positive correlation values. Besides, in Jundiaí do Sul Syphrea sp. 4, the second most abundant species, showed higher and significant positive correlation with Chrysomelidae than the first one, Epitrix sp. 6 (Table 2).

When the data were grouped by seasons (Figure 3), chrysomelids occurred mainly during spring and/or summer. Similar patterns were found in Telêmaco Borba, Guarapuava, Jundiaí do Sul, Fênix and Colombo, where the highest capture occurred in the same season in both years, spring at the first four sites and summer in Colombo. In other sites the peaks occurred in spring in one year and summer in other. The lowest abundances occurred in autumn or winter. The highest species richness of Chrysomelidae was recorded in the seasons with the highest abundances (Figure 3).

\section{Seasonal pattern of the ten dominant Chrysomelidae species}

The ten most abundantly captured species (2.2\% of the species; Table 3 ) represented $44.7 \%$ of all Chrysomelidae specimens sampled; $78.5 \%$ of the species had less than ten individuals, and $19.3 \%$ had its abundance sparsely distributed along the years (Linzmeier \& Ribeiro-Costa 2012) not being possible to study its seasonal pattern.

The dominant species, nine Alticini (Galerucinae) and one Eumolpinae, showed different seasonal patterns at the sites where they were most abundant (Table 3; Figure 4).

Margaridisa sp., with 92.5\% collected in Antonina, showed a considerable peak in December 1987 and two smaller in November 1986 and March 1987 (Figure 4). Neothona prima, collected almost exclusively in Ponta Grossa, showed very marked seasonality with the first peak in October 1986 and another in September 1987, followed by a smaller peak in January in both years. Dinaltica gigia was also collected almost exclusively in Ponta Grossa, but did not show a clear seasonal pattern over the years. However, the largest captures were in February 1987 and in March 1988. Genaphtona yasmina, with $94.3 \%$ of the total collected in Ponta Grossa, also did not show a clear seasonal pattern. There were two peaks, one in January 1987 and another in April 1987, and a much smaller one in March 1988. Diphaltica sp., collected only in São José dos Pinhais, showed very marked seasonality, with peaks in November in both years, and was almost exclusively recorded from October to December. Most Epitrix sp. 6 specimens were obtained from Jundiaí do Sul. Its abundance peaked in May in both years, with smaller peaks in October 1986 and January 1988. Eumolpinae sp. 24, with 63.7\% collected in Colombo, was captured almost exclusively in the second year, from December 1987 to February 1988, with a maximum in January 1988. The other specimens of this species were caught in Telêmaco Borba, in both years with a peak in December 1986. Trichaltica micros, collected almost exclusively in Ponta Grossa, showed a clear seasonal pattern, with peaks in December 1986 and January 1988. It was almost never

Table 2. Correlation between monthly mean abundance of Chrysomelidae and total Coleoptera captured with Malaise traps and between monthly mean abundance of Chrysomelidae and the two dominant species of each sampled site in the state of Paraná, Brazil, from August 1986 to July 1988 . Values followed by $*$ had significant correlation $(\mathrm{p}<0.05)$.

\begin{tabular}{|c|c|c|c|c|c|c|c|c|}
\hline & ANT & SJ & CO & PG & TB & GUA & $\mathbf{J U}$ & FE \\
\hline Chrysomelidae x Coleoptera & $0.92 *$ & $0.99 *$ & $0.95 *$ & $0.70^{*}$ & $0.95^{*}$ & $0.92 *$ & $0.88 *$ & $0.67 *$ \\
\hline Chrysomelidae x $1^{\text {st }}$ sp. + abundant & $0.98 *$ & $0.89 *$ & $0.88 *$ & $0.84 *$ & 0.18 & 0.26 & 0.21 & $0.75 *$ \\
\hline Chrysomelidae $x 2^{\text {nd }}$ sp. + abundant & 0.37 & 0.26 & $0.59 *$ & -0.11 & 0.16 & 0.14 & $0.79 *$ & $0.66^{*}$ \\
\hline
\end{tabular}

ANT: Antonina; SJ: São José dos Pinhais; CO: Colombo; PG: Ponta Grossa; TB: Telêmaco Borba; GUA: Guarapuava; JU: Jundiaí do Sul; FE: Fênix.

Table 3. The ten dominant Chrysomelidae species sampled with Malaise traps in eight sites of Paraná, Brazil, from August 1986 to July 1988 and its correlation with meteorological variables. All taxa except Eumolpinae sp. 24 belong to Alticini (Galerucinae). Values followed by $*$ had significant correlation ( $\mathrm{p}<0.05$ ).

\begin{tabular}{|c|c|c|c|c|c|c|c|c|}
\hline & $\mathbf{N}_{\text {total }}$ & $\mathbf{N}_{\text {local }}$ & Local & $\mathbf{T}_{\max }$ & $\mathbf{T}_{\min }$ & $\mathbf{R H}$ & Rain & $\mathbf{P P}$ \\
\hline Margaridisa sp. & 922 & 853 & ANT & $0.57^{*}$ & $0.47 *$ & $-0.65 *$ & 0.07 & $0.66^{*}$ \\
\hline Neothona prima Bechyné, 1955 & 668 & 662 & PG & 0.01 & 0.02 & -0.14 & -0.20 & 0.29 \\
\hline Dinaltica gigia Bechyné, 1956 & 349 & 344 & PG & 0.19 & 0.27 & 0.21 & 0.12 & -0.12 \\
\hline Genaphtona yasmina Bechyné, 1955 & 227 & 214 & PG & $0.48 *$ & $0.50 *$ & 0.25 & 0.09 & 0.23 \\
\hline Diphaltica sp. & 219 & 219 & SJ & 0.24 & 0.24 & 0.10 & -0.03 & $0.47^{*}$ \\
\hline Epitrix sp. 6 & 216 & 200 & JU & -0.22 & -0.12 & 0.13 & -0.02 & -0.38 \\
\hline Eumolpinae sp. 24 & 202 & 129 & $\mathrm{CO}$ & $0.49 *$ & 0.40 & -0.24 & 0.31 & 0.35 \\
\hline Monoplatus ocularis Bechyné, 1955 & 200 & 178 & $\mathrm{CO}$ & 0.21 & 0.12 & -0.26 & -0.11 & 0.19 \\
\hline Trichaltica micros Bechyné, 1954 & 193 & 190 & PG & $0.65 *$ & $0.70 *$ & -0.03 & 0.16 & $0.61^{*}$ \\
\hline Syphrea sp.4* & 190 & 186 & JU & $0.46^{*}$ & 0.34 & -0.34 & 0.13 & $0.42^{*}$ \\
\hline
\end{tabular}

$\mathrm{N}_{\text {total }}$ : Total abundance; $\mathrm{N}_{\text {local }}$ : abundance at the site where species was most abundant; Local: site where the species was most abundant; $\mathrm{T}_{\text {max }}$ : maximum temperature; $\mathrm{T}_{\min }$ : minimum temperature; RH: relative humidity; Rain: rainfall; PP: Photoperiod. ANT: Antonina; SJ: São José dos Pinhais; CO: Colombo; PG: Ponta Grossa; JU: Jundiaí do Sul. 

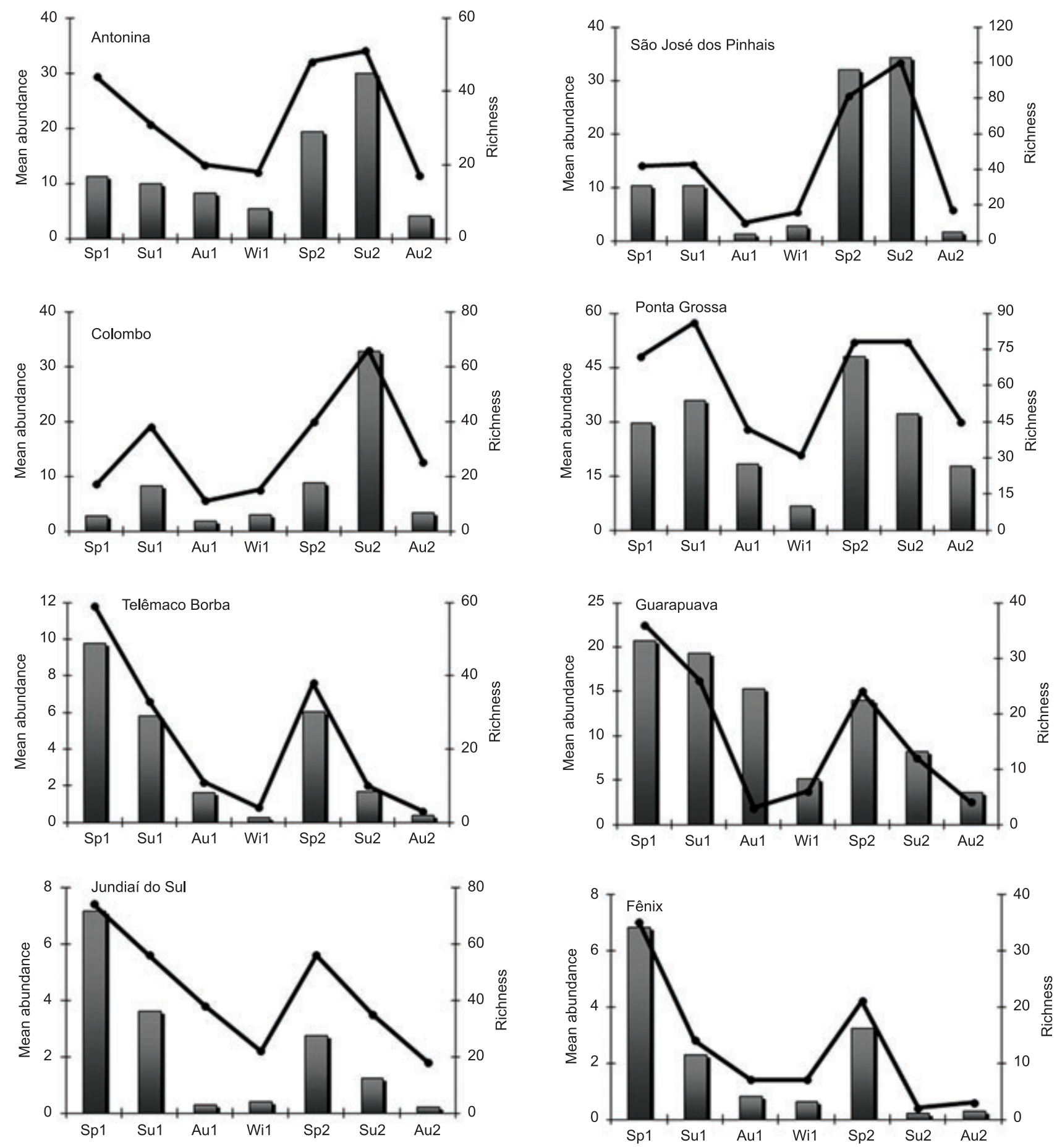

Figure 3. Seasonal distribution pattern of Chrysomelidae abundance and species richness sampled with Malaise traps along the seasons in eight sites of the state of Paraná, Brazil, from August 1986 to July 1988. * Columns represent the mean abundance by season and line the total species richness. Sp: spring; Su: summer; Au: autumn; Wi: winter; the numbers following the seasons name represent the year of sample (1: first year; 2 : second year).

recorded in winter. Finally, Monoplatus ocularis, with $89 \%$ collected in Colombo, had no clear seasonal pattern, because several peaks were observed during both years as with Syphrea sp. 4, which was collected almost exclusively in Jundiaí do Sul.

Significant correlations were found for Margaridisa sp. abundance with maximum and minimum temperature, relative humidity and photoperiod, for T. micros abundance with maximum and minimum temperature and photoperiod, for G. yasmina abundance with maximum and minimum temperatures, for Syphrea sp. 4 abundance with maximum temperature and photoperiod, for Eumoplinae sp. 24 abundance with maximum temperature, and for Diphaltica sp. abundance with photoperiod (Table 3). Neothona prima, D. gigia, Epitrix sp. 6, M. ocularis abundances were not correlated with any of the variables analyzed (Table 3 ). 

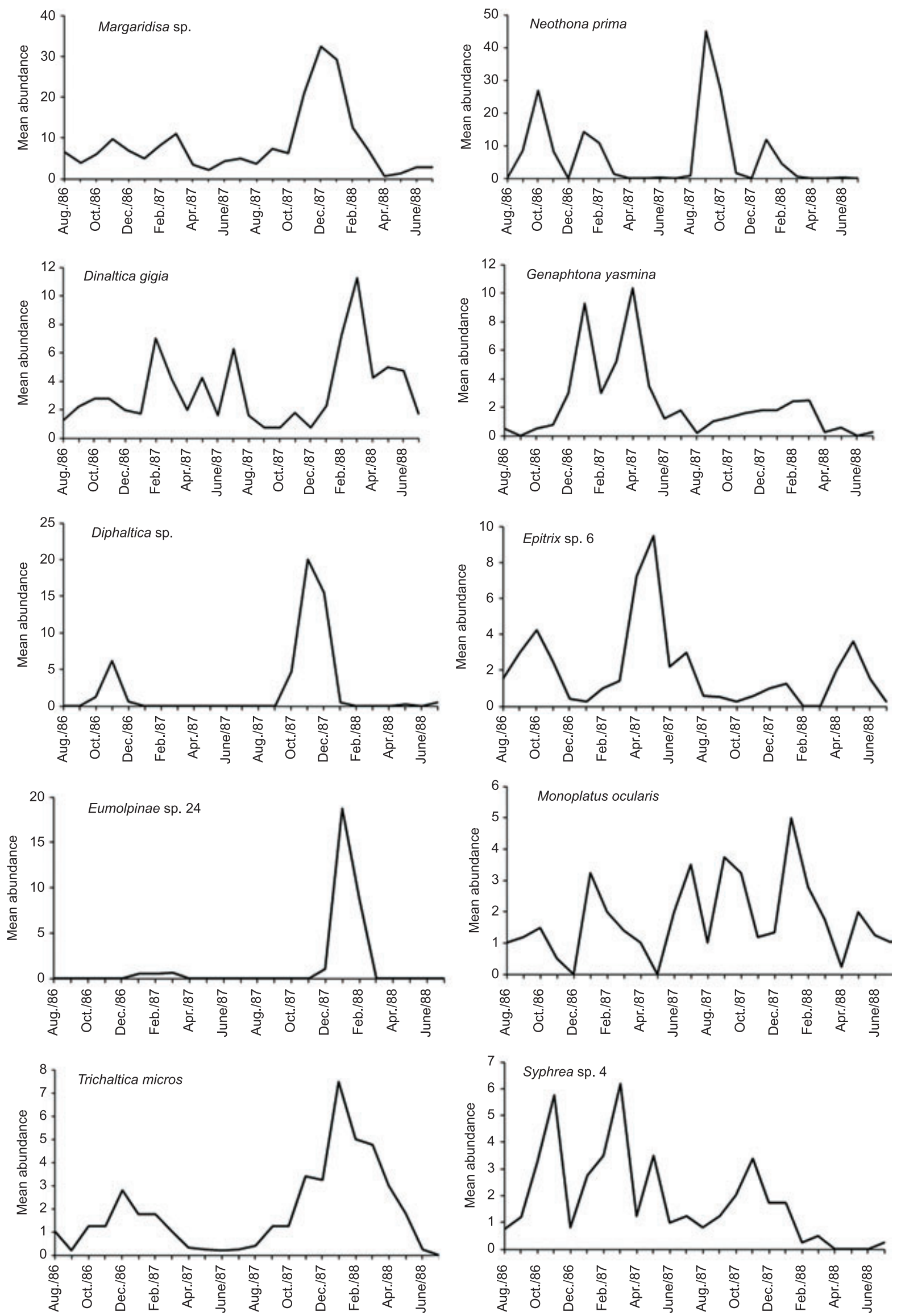

Figure 4. Seasonal distribution pattern of the ten dominant Chrysomelidae species sampled with Malaise traps in the state of Paraná, Brazil, from August 1986 to July 1988. 


\section{Discussion}

\section{Seasonal pattern of Chrysomelidae}

The decrease of Chrysomelidae abundance from 1986 to 1988 in Jundiaí do Sul is difficult to be explained, although the increase in São José dos Pinhais, even not significant, may be explained by a higher mean maximum temperature $\left(19.9^{\circ} \mathrm{C}\right)$ and lower rainfall $(577.7 \mathrm{~mm})$ in the months from October to December and the reverse in the first year $\left(17.9^{\circ} \mathrm{C} ; 824 \mathrm{~mm}\right)$. During 1986 and 1987, there was a moderate El Niño, during which the rains are more abundant than in normal years and temperatures decrease (Cesar Duquia, personal comm.). This phenomenon may have contributed in some way on the Chrysomelidae captures.

The similarity of the abundance pattern of Chrysomelidae and total Coleoptera is probably related to the dominance of herbivorous families sampled by Malaise. In Fênix and mainly in Ponta Grossa where differences between the patterns of these groups were largest, it is possible that families of non herbivorous beetles dominated and influenced the pattern of total Coleoptera. The most abundant species in Antonina, São José dos Pinhais, Colombo, Ponta Grossa and Fênix, that are Margaridisa sp., Diphaltica sp., Eumolpinae sp. 24, N. prima and Eumolpinae sp. 7, respectively, and the second most abundant in Colombo and Fênix, M. ocularis and Syphrea sp. 3, respectively, are representing and influencing the distribution pattern of the family at these sites. However, in Jundiaí do Sul the second most abundant species, Syphrea sp. 4, most influenced the Chrysomelidae pattern found, since the first one Epitrix sp. 6, showed a differentiated pattern with its higher abundances in autumn/winter.

Photoperiod was the variable with the highest correlation values being the most significant in the Chrysomelidae seasonality in most sites, corroborating the earlier findings of Linzmeier \& Ribeiro-Costa (2008). Another variable correlated with the seasonal pattern was the temperature. Wolda (1978a) considered these the main factors determining changes in species abundance in temperate regions and, Marques et al. (2004) also reported them as those most closely correlated with plant phenology in an Araucaria forest in Paraná. In Fênix the relative humidity showed to be the most important variable, probably acting on the flight activity of the chrysomelids as well as for Diptera (Marinoni \& Bonatto 2002, Costacurta et al. 2003).

At all sites, the Chrysomelidae showed a marked seasonal pattern with the largest captures in spring and/or summer and smallest in winter as reported earlier by Linzmeier \& Ribeiro-Costa (2008). This pattern has also been observed for several groups of insects sampled at these same sites as Lepidoptera, Trichoptera, Diptera (Muscidae and Syrphidae) (Marinoni \& Dutra 1996, Almeida \& Marinoni 2000, Marinoni \& Bonatto 2002, Costacurta et al. 2003). Following Linzmeier \& Ribeiro-Costa (2008), the elevated number of species and specimens at these seasons are related to higher food availability/quality since is in this period that the leaves sprout. Herbivores generally prefer to consume young leaves (Jolivet 1988, Novotný \& Basset 1998, Alonso \& Herrera 2000), which are more nutritious, with higher water and nitrogen content and less chemical defenses such as tannins and resins (Wolda 1978b). In addition, in the spring/summer, some species, especially the Eumolpinae, have been associated to the presence of flowers (Basset \& Samuelson 1996).

Since budding and flowering in Araucaria forests occur during the wettest months, September to December (Marques et al. 2004), and as Colombo, Ponta Grossa, Telêmaco Borba and Guarapuava are included in this ecosystem, there seems to be a congruence between the phenological patterns of plants and the abundance peak of Chrysomelidae at these sites, which were also more similar in Chrysomelidae species composition according to Linzmeier \& Ribeiro-Costa (2012).

However, as plants are not only subjected to regional climate variations, but also to local environmental variations (Marques \& Oliveira 2004), it is possible that changes in the occurrence peaks of Chrysomelidae may be related to variations on this scale. Other factors are predation and competition for resources. Predation can act to determine the seasonal pattern of the species, and Chrysomelidae display a wide range of predator avoidance behaviors. Among the groups mainly collected in this study (Galerucinae-Alticini and Eumolpinae) two important strategies are found: both have many species root feeders in larval stages and free leaf eaters as adults, and Alticini has another effective behavior, the ability to jump (Ge et al. 2011). Besides, since herbivores have similar ecological requirements, interspecific competition is a major cause of community structure (Schluter \& Ricklefs 1993) and Linzmeier \& Ribeiro-Costa (2008) found that the Alticini (Chrysomelidae) of Ponta Grossa was structured in the seasons with food competition being the most likely cause.

Among the sites, Jundiaí do Sul stands out due to the relatively high chrysomelid abundance in all seasons but especially in autumn. One possible hypothesis to explain this high abundance is the geographical position of this site, at lower latitude in the northern part of the state. Wolda (1988) pointed that the lower the latitude, the longer the period of growth and reproduction of plants and animals. Thus, it is possible that the period of chrysomelid occurrence tends to be longer at this site, increasing the number of generations. However, contrary to the proposal of Wolda (1988) that rainfall, at lower latitudes, has a greater influence on species seasonality, such variable in Jundiaí do Sul had not much influence on the seasonality of Chrysomelidae.

\section{Seasonal pattern of the ten dominant Chrysomelidae species}

Unlike the Chrysomelidae pattern, the peaks of Epitrix sp. 6, Syphrea sp. 4 and G. yasmina were in the months of autumn or winter. Syphrea sp. 4, which was the second most abundant species in Jundiaí do Sul, with a peak in autumn, most influenced the Chrysomelidae pattern at this site; G. yasmina, abundant in Ponta Grossa, also showed a peak in autumn.

Most species seem to have at least two generations per year. For $N$. prima, this pattern is evident and well delimited by the presence of a peak in early spring and a smaller one in the summer. Margaridisa sp., D. gigia, G. yasmina, Epitrix sp. 6, M. ocularis, T. micros and Syphrea sp. 4 seem to be multivoltine since they occurred along the years. These species are likely to be generalists consuming different plant species, resulting in their occurrence throughout the years sampled. Only Diphaltica sp. and Eumolpinae sp. 24 are probably univoltine, occurring only in spring/summer and each one should be restrict to a specific host species.

Of the ten species, D. gigia, M. ocularis, one species of Trichaltica and one of Syphrea were also collected in large numbers by Linzmeier et al. (2006) in Ponta Grossa. Assessing the seasonality of these species, the first two were shown to have a pattern similar to that found in the present study. The Trichaltica species, T. elegantula Baly, 1876, occurred only from September to November and was recorded feeding on flowers of Allophylus edulis (St. Hil) Radlk (Sapindaceae) (Linzmeier \& Ribeiro-Costa 2009). According to Bechyné (1997), species of this genus are found on flowers, sometimes damaging them. Thus, T. micros, one of the most collected species in this work, should also feed on flowers, but it seemed to be more generalist since it occurred in almost all the months, being more abundant in spring/ summer. The Syphrea species, S. olga Bechyné, 1955, like Syphrea 
sp. 4, was collected during the whole period, with peaks in winter. Unlike Syphrea sp. 4, S. olga occurred in spring and autumn, with a peak in the latter season.

Temperature and photoperiod were also the main factors influencing the population of the species, but some species were not correlated with any variable. Besides abiotic factors, biological and behavioral characteristics of each species act to determine their seasonal pattern. Basset \& Samuelson (1996) attempted to determine the seasonal pattern of some Chrysomelidae species in Papua New Guinea, and even knowing the identity and phenology of various plants, they were unable to correlate the peaks of chrysomelid activity to the phenology of their hosts. Furthermore, the abiotic variables measured by these authors did not show significant correlations with the species' activity, showing the difficulty of conducting this kind of study.

Unfortunately, little is known about the species studied here. It is only known that several Epitrix Foudras, 1859 species, that are worldwide distributed, are agricultural pests, leaf borers and generally attack solanaceous plants, causing damage to several crops (Bechyné 1997, Gallo et al. 2002). In the case of Margaridisa and Syphrea, which are also leaf borers, their host plants are recorded to be Ricinus communis L. (Euphorbiaceae), Acalypha sp. (Euphorbiaceae) and Hibiscus rosa-sinensis L. (Malvaceae) for Margaridisa and, Passiflora sp. (Passifloraceae) and Syzygium jambos L. (Alston) (Myrtaceae) for Syphrea (Bechyné 1997, Riley et al. 2002). Taking into account this information, it is possible that the species of Margaridisa and Syphrea collected in this study can be associated with Hibiscus and Passiflora species, respectively, since Hibiscus is a plant widely used as a hedge in Antonina and Passiflora is quite common in the forests and easily found at the sites sampled.

This work presents for the first time a comprehensive study on the seasonality of Chrysomelidae at southern of Brazil from samples at eight sites in Paraná over two consecutive years. The patterns found follow the general pattern of subtropical region where the higher captures of insects occur in the spring/summer. However, to better understand the seasonal patterns of chrysomelids in subtropical regions, it is necessary to extend studies on the natural history of the Chrysomelidae species.

\section{Acknowledgments}

We are grateful to Dr. Renato C. Marinoni (Departamento de Zoologia, Universidade Federal do Paraná, in memoriam) for material provided, to César Duquia (Instituto Tecnológico SIMEPAR) for the information about El Niño, to the anonymous reviewers for the valuable suggestions and to the Conselho Nacional de Desenvolvimento Científico e Tecnológico (CNPq) for awarding scholarships to the authors. This article represents contribution number 1858 of Departamento de Zoologia, Universidade Federal do Paraná, Curitiba, Brazil.

\section{References}

ALMEIDA, G.L. \& MARINONI, L. 2000. Abundância e sazonalidade das espécies de Leptoceridae (Insecta, Trichoptera) capturadas com armadilha luminosa no Estado do Paraná, Brasil. Rev. Bras. Zool. 17(2):347-359. http://dx.doi.org/10.1590/S0101-81752000000200005

ALONSO, C. \& HERRERA, C.M. 2000. Seasonal variation in leaf characteristics and food selection by larval noctuids on an evergreen Mediterranean shrub. Acta Oecol. 21:257-265. http://dx.doi.org/10.1016/ S1146-609X(00)01082-1

BASSET, Y. \& SAMUELSON, G.A. 1996. Ecological characteristics of an arboreal community of Chrysomelidae in Papua New Guinea. In Chrysomelidae Biology: Ecological Studies (P. Jolivet \& M.L. Cox, eds.). Academic Publishing, Amsterdam, p.243-262.
BECHYNÉ, J. 1997. Evaluación de los datos sobre los Phytophaga daniños en Venezuela (Coleoptera) Parte I. Bol Entomol Venez, Ser Monog. 1:1-278.

BOUCHARD, P., GREBENNIKOV, V.V., SMITH, A.B.T. \& DOUGLAS, H. 2009. Biodiversity of Coleoptera. In Insect biodiversity: science and society (R.G. Foottit \& P.H. Adler, eds.). Blackwell Publishing, Oxford, p.265-301. http://dx.doi.org/10.1002/9781444308211.ch11

COSTA, C. 2000. Estado de conocimiento de los Coleoptera Neotropicales. In Hacia un Proyecto CYTED para el Inventario y Estimación de la Diversidad Entomológica en Iberoamérica: PrIBES-2000 (F. MartínPiera, J.J. Morrone \& A. Melic, eds.). Sociedad Entomológica Aragonesa, Zaragoza, v.1, p.99-114.

COSTACURTA, N.C., MARINONI, R.C. \& CARVALHO, C.J.B. 2003. Fauna de Muscidae (Diptera) em três localidades do Estado do Paraná, Brasil, capturada por armadilha Malaise. Rev. Bras. Entomol. 47(3):389-397. http://dx.doi.org/10.1590/S0085-56262003000300005

DANKS, H.V. 2007. The elements of seasonal adaptations in insects. Can. Entomol. 139:1-44. http://dx.doi.org/10.4039/n06-048

FURTH, D.G., LONGINO, J.T. \& PANIAGUA, M. 2003. Survey and quantitative assessment of flea beetle diversity in a Costa Rican rainforest (Coleoptera: Chrysomelidae: Alticinae). In Special topics in leaf beetle biology (D.G. Furth, ed.). Russia, Moscow, p.1-23.

GALLO, D., NAKANO, O., SILVEIRA NETO, S., CARVALHO, R.P.L., BAPTISTA, G.C., BERTI FILHO, E., PARRA, J.R.P., ZUCCHI, R.A., ALVES, S.B., VENDRAMIM, J.D., MARCHINI, L.C., LOPES, J.R.S. \& OMOTO, C. 2002. Entomologia Agrícola. Fundação de estudos agrários Luiz de Queiroz, Piracicaba, 920p.

GANHO, N.G. \& MARINONI, R.C. 2003. Fauna de Coleoptera no Parque Estadual de Vila Velha, Ponta Grossa, Paraná, Brasil. Abundância e riqueza das famílias capturadas através de armadilhas armadilha Malaise. Rev. Bras. Zool. 20(4):727-736. http://dx.doi.org/10.1590/ S0101-81752003000400028

GE, D., CHESTERS, D., GÓMEZ-ZURITA, J., ZHANG, L., YANG, X. \& VOGLER, A.P. 2011. Anti-predator defense drives parallel morphological evolution in flea beetles. Proc. R. Soc. B 278:2133-2141. http://dx.doi. org/10.1098/rspb.2010.1500

JOLIVET, P. 1988. Food habits and food selection of Chrysomelidae: Bionomic and evolutionary perspectives. In Biology of Chrysomelidae (P. Jolivet \& T.H. Hsiao, eds.). Kluwer Academic Publishers, Dordrecht, p.1-24. http://dx.doi.org/10.1007/978-94-009-3105-3_1

JOLIVET, P. 1992. Insects and plants: parallel evolution and adaptations. Sandhill Crane Press.

JOLIVET, P. \& HAWKESWOOD, T.J. 1995. Host-plants of Chrysomelidae beetles of the world: an essay about the relationships between leaf beetles and their food-plants. Backhuys Publishers, Leiden.

LINZMEIER, A.M. \& RIBEIRO-COSTA, C.S. 2008. Seasonality and temporal structuration of Alticini community (Coleoptera, Chrysomelidae, Galerucinae) in the Araucaria Forest of Parana, Brazil. Rev. Bras. Entomol. 52(2):289-295. http://dx.doi.org/10.1590/S008556262008000200009

LINZMEIER,A.M. \& RIBEIRO-COSTA, C.S. 2009. Spatio-temporal dynamics of Alticini (Coleoptera, Chrysomelidae) in a fragment of Araucaria Forest in the state of Parana, Brazil. Rev. Bras. Entomol. 53(2):294-299. http:/ dx.doi.org/10.1590/S0085-56262009000200013

LINZMEIER, A.M. \& RIBEIRO-COSTA, C.S. 2012. Spatial-temporal composition of Chrysomelidae (Insecta: Coleoptera) communities in southern Brazil. J. Nat. Hist. 46:1921-1938. http://dx.doi.org/10.1080/0 0222933.2012.707237

LINZMEIER, A.M., RIBEIRO-COSTA, C.S. \& MARINONI, R.C. 2006. Fauna de Alticini (Newman) (Coleoptera, Chrysomelidae, Galerucinae) em diferentes estágios sucessionais na Floresta com Araucária do Paraná, Brasil: diversidade e estimativa de riqueza de espécies. Rev. Bras. Entomol. 50(1):101-109. http://dx.doi.org/10.1590/S008556262006000100015

LEHMANN, E.L. \& D’ABRERA, H.J.M. 1998. Nonparametrics: Statistical Methods Based on Ranks. rev. ed. Upper Saddle River, Prentice-Hall. 
MARINONI, L. \& BONATTO, S.R. 2002. Sazonalidade de três espécies de Syrphidae (Insecta, Diptera) capturadas com armadilha Malaise no Estado do Paraná, Brasil. Rev. Bras. Zool. 19(1):95-104. http://dx.doi. org/10.1590/S0101-81752002000100007

MARINONI, R.C. \& DUTRA, R.R. 1993. Levantamento da fauna entomológica no Estado do Paraná. I. Introdução. Situações climática e florística de oito pontos de coleta. Dados faunísticos de agosto de 1986 a julho de 1987. Rev. Bras. Zool. 8(1-2):31-73.

MARINONI, R.C. \& DUTRA, R.R. 1996. Levantamento da fauna entomológica no Estado do Paraná. II. Ctenuchidae (Lepidoptera). Rev. Bras. Zool. 13(2):435-461. http://dx.doi.org/10.1590/S010181751996000200014

MARINONI, R.C. \& DUTRA, R.R. 1997. Famílias de Coleoptera capturadas com armadilha Malaise em oito localidades do Estado do Paraná, Brasil. Diversidade alfa e beta. Rev. Bras. Zool. 14(3):751-770. http://dx.doi. org/10.1590/S0101-81751997000300021

MARINONI, R.C. \& GANHO, N.G. 2003. Sazonalidade de Nyssodrysina lignaria (Bates) (Coleoptera, Cerambycidae, Lamiinae), no Estado do Paraná, Brasil. Rev. Bras. Zool. 20(1):141-152. http://dx.doi.org/10.1590/ S0101-81752003000100018

MARQUES, M.C.M. \& OLIVEIRA, P.E.A.M. 2004. Fenologia de espécies do dossel e do sub-bosque de duas Florestas de Restinga na Ilha do Mel, sul do Brasil. Rev. Bras. Bot. 27(3):713-723.

MARQUES, M.C.M., ROPER, J.J. \& SALVALAGGIO, A.P.B. 2004. Phenological patterns among plant life-forms in a subtropical forest in southern Brazil. Plant Ecol. 173:203-213. http://dx.doi.org/10.1023/ B:VEGE.0000029325.85031.90

MOREIRA, J.L.K. 2009. Anuário Interativo do Observatório Nacional [internet]. Observatório Nacional, Ministério da Ciência, Tecnologia e Inovação, Rio de Janeiro. http://euler.on.br/ephemeris/index.php (último acesso em 10/03/2009).

NETHERER, S. \& SCHOPF, A. 2010. Potential effects of climate change on insect herbivores in European forests - General aspects and the pine processionary moth as specific example. For. Ecol. Manage. 259:831-838. http://dx.doi.org/10.1016/j.foreco.2009.07.034
NOVOTNÝ, V. \& BASSET, Y. 1998. Seasonality of sap-sucking insects (Auchenorrhyncha, Hemiptera) feeding on Ficus (Moraceae) in a lowland rain forest in New Guinea. Oecologia 115:514-522. http://dx.doi. org/10.1007/s004420050549

REID, C.A.M. 1995. A cladistic analysis of subfamilial relationships in the Chrysomelidae sensu lato (Chrysomeloidea). In Biology, Phylogeny and Classification of Coleoptera: Papers Celebrating the $80^{\text {th }}$ Birthday of Roy A. Crowson (J. Pakaluk \& S.A. Slipinski, eds.). Muzeum i Instytut Zoologii PAN, Warszawa, p.559-631.

RIEDEL, R., MARINONI, R.C. \& MARTINS-OPOLIS, N. 2007. Spatio-temporal trends of insect communities in Southern Brazil. J. Entomol. 5(6):369-380. http://dx.doi.org/10.3923/je.2008.369.380

RILEY, E.G., CLARK, S.M., FLOWERS, R.W. \& GILBERT, A.JR. 2002. Chrysomeloidea. In American Beetles Polyphaga: Scarabaeoidea through Curculionoidea (R.H. Arnett, M.C. Thomas, P.E. Skelley \& J.H. Frank, eds.). CRC Press LLC, Boca Raton, p.617-691.

SCHLUTER, D. \& RICKLEFS, R.E. 1993. Species diversity: an introduction to the problem. In Species diversity in ecological communities: historical and geographical perspectives (R.E. Ricklefs \& D. Schluter, eds.). University of Chicago Press, Chicago, p.1-10.

VELOSO, H.P. \& GÓES-FILHO. 1982. Fitogeografia Brasileira. Classificação fisionomica-ecológica da vegetação neotropical. Bol. Tec. Projeto RADAMBRASIL, Série Vegetação.

StatSoft, Inc. 2007. STATISTICA (data analysis software system). version 8.0. www.statsoft.com

WOLDA, H. 1978a. Fluctuations in abundance of tropical insects. Am. Nat. 112:1017-1045. http://dx.doi.org/10.1086/283344

WOLDA, H. 1978b. Seasonal fluctuations in rainfall, food and abundance of tropical insects. J. Anim. Ecol. 47:369-381. http://dx.doi.org/10.2307/3789

WOLDA, H. 1979. Seasonality parameters for insect populations. Res. Popul. Ecol. 20:247-256. http://dx.doi.org/10.1007/BF02512630

WOLDA, H. 1988. Insect seasonality: why? Annu. Rev. Ecol. Syst. 19:1-18. 